\title{
Reuse of Ground Granulated Blast Furnace Slag (GGBFS) in Lime Stabilized Embankment Materials
}

\author{
A. Kavak and G. Bilgen
}

\begin{abstract}
This paper presents an effective way of utilizing the ground granulated blast furnace slag (GGBFS), which is a by-product of the steel manufacturing process with lime for stabilization of road materials. In the study Ankara clay was used for stabilization. Although slag-lime and clay mixtures do not affect optimum water contents of clay significantly, they decrease dry density and smoothes Proctor curve. Then, the soil transforms into a rapid structure and the modulus of elasticity increases. When the results of the experiments were evaluated, unconfined compressive strength (UCS) and soaked California Bearing Ratio (CBR) values of the soils have shown significant increases. These increases reach to 46 times in CBR values for Ankara clay compared to natural case in $\mathbf{2 8}$ day-cured samples. This stabilization technique is more effective than the lime alone and also the slag will prevent the ettringite formation that occurs in lime stabilization with sulfate rich soils that leads swelling behaviour. And finally the slag may turn from a waste material into a valuable product for road construction works with huge volumes even at far away from the steel factories.
\end{abstract}

Index Terms_Clay, lime, slag, stabilization.

\section{INTRODUCTION}

Soil stabilization occurs when additives are added to a reactive soil to generate long-term strength gain through pozzolanic reactions. There are many stabilization additives for the soil improvement that are widely used in the world. A few of these additives are cement, lime, slag, fly ash and various chemicals. Particularly lime is a very effective and widely used material for soil stabilization. Lime stabilization of clay type of soils has been widely used in fill layers of foundations or highway embankments as an economical method to avoid the more expensive process of transporting in large quantities of granular fill.

The addition of lime modifies the response of the soil system to water and a number of reactions take place. Four types of reactions can take place during stabilization of clay type of soils with lime: (i) cation exchange, (ii) flocculation and particle aggregation, (iii) lime carbonation and (iv) pozzolonic reactions between lime, silica and alumina. These procedures all play some role: the first three however can probably be regarded as side effects rather than as the actual case [1]. Reactions (i) and (ii) lead to immediate reactions and improvement in soil plasticity, workability, uncured strength and load-deformation properties. Reactions (iii) and

Manuscript received May 30, 2014; revised August 23, 2014. This work was supported in part by the project is numbered2012-M1-00-03 of Scientific Research Support of Bulent Ecevit University.

A. Kavak is with the Department of Civil Engineering, Kocaeli University, Kocaeli, Turkey (e-mail: aydinkavak@yahoo.com).

G. Bilgenwas with Alaplı Vocational School, Bulent Ecevit University, Zonguldak, Turkey (e-mail: bilgamze@gmail.com). (iv) leads to the formation of cementing products. Pozzolonic reactions are responsible for long-term increase in soil strength with little or no change in water content, even many months and years after mixing and compaction [2]. Lime can modify almost all fine-grained soils, but the most dramatic improvements occur in clay soils of moderate to high plasticity.

Slag provides improved resistance to sulfate attack of concrete or mortar in seawater or other aggressive environments Tasong [3]. Similar to the chemical structure of GGBFS, the main components of cement and limestone include silicate and aluminum in its chemical structure. It is a known fact that GGBFS can be used as aggregate in concrete Cevik [4] and has a pozzolanic effect on cement. Wild [5] stated that; the use of ground granulated blast furnace slag, an industrial by-product, is well established as a binder in many cement applications where it provides enhanced durability and high resistance to sulfate attack. When the use of slag in soil stabilization is examined, Veith [6] states that; the soil stabilized with lime-activated slag has shown significant strength enhancement relative to lime-stabilized soil and also very good volume stability when subjected to water in presence of the aggressive sulphates. The changes in the chemical structure of the clays are examined and the fact that the slag decreases the swelling potential of the clays and strengthen achieved particularly, in the study of Veith [6] done on clays using $5 \%$ lime, $1 \%$ GGBFS and in the studies of Wild [5] et al. Slag is a highly important problem in iron and steel factories. Slag heaps are formed due to the iron production in the factories. In some areas it is poured into the sea and sometimes it is used in concrete production in small proportion compared to the total volume produced. An average of 300 kilograms ( $30 \%$ percentage), waste slag occurs in one-ton steel production. The value of slag increases each year at a rate proportional to steel production. The possibility of being able to recycle or process waste materials such as GGBFS has great potential economic benefits in all construction industry.

The objective of this study is to investigate the conditions of usage of GGBFS as an additive for road fill materials. In general, lime alone is a very good additive to stabilize clay type of soils and frequently used for embankment works. In the previous studies [7], it was observed that slag alone as an additive did not lead to considerable improvements in the clay type of soils. In this study, an alternative methodology was presented to use the pulverized GGBFS as a second additive for clay type of soil with lime. This methodology may lead to an economical usage of GGBFS for improvement and stabilization as an additive of road construction materials with lime and also may cause GGBFS to be a valuable material instead of a waste material. 


\section{Methodology}

In the study, brown colored Ankara clay was used in the research such as Kavak et al. used [8] for a field stabilization application with lime. Atterberg limit tests, sieve analysis, and Proctor test were applied to determine the typical geotechnical properties of the natural clay. Summary of these test results are given in Table I. Optimum lime content was found as 5\% after $\mathrm{pH}$ and Atterberg limits tests as defined in section 2.1. Two different slag amounts were used for the maximization of the strength of the soil using unconfined compression tests. In the study, the comparisons were done for the cases i) natural soil ii) clay with $5 \%$ of lime by weight iii) clay with $5 \%$ lime and $3.33 \%$ pulverized GGBFS and iv) clay with $3.33 \%$ lime and $3.33 \%$ pulverized GGBFS.

\begin{tabular}{ll} 
TABLE I: GEOTECHNICAL PROPERTIES OF ANKARA CLAY \\
\hline \hline Natural water content (\%) & 10 \\
Soil classification & $\mathrm{CH}$ \\
Clay+silt ( \%) & 98 \\
Clay (\%) & 36 \\
Liquid limit (\%) & 70 \\
Plastic limit (\%) & 35 \\
Plasticity index (\%) & 35 \\
$\quad \mathrm{k}\left(\mathrm{kN} / \mathrm{m}^{3}\right)$ (modified) & 15,5 \\
Opt. w (\%) (modified) & 20,5 \\
Soaked CBR & 4 \\
pH Value & 7,7 \\
Activity & 1,31 \\
\hline \hline
\end{tabular}

Moisture and density relations of the soil were determined using modified Proctor compaction tests. The tests were conducted according to the ASTM D 698-78 and D 1557-78 [9]. Following these tests, comparisons were made of the behavior of the lime stabilized soil with natural conditions. The experiments were performed after waiting for $1 \mathrm{hr}$. to let the first reactions to take place upon mixing the determined amount of lime and water to the natural dry samples. Results are shown in Table II.

TABLE II: MODIFIED PROCTOR TESTS FOR ALL THE CASES

\begin{tabular}{lcc}
\hline \hline Mixtures & MDUW $\left(\mathrm{kN} / \mathrm{m}^{3}\right)$ & Optimum water content $(\%)$ \\
\hline Natural clay & 15.51 & 20.50 \\
$\mathrm{C}+5 \% \mathrm{~L}$ & 14.60 & 26.00 \\
$\mathrm{C}+5 \% \mathrm{~L}+3.33 \% \mathrm{~S}$ & 14.70 & 25.50 \\
$\mathrm{C}+3.33 \% \mathrm{~L}+3.33 \% \mathrm{~S}$ & 14.75 & 26.00 \\
\hline \hline
\end{tabular}

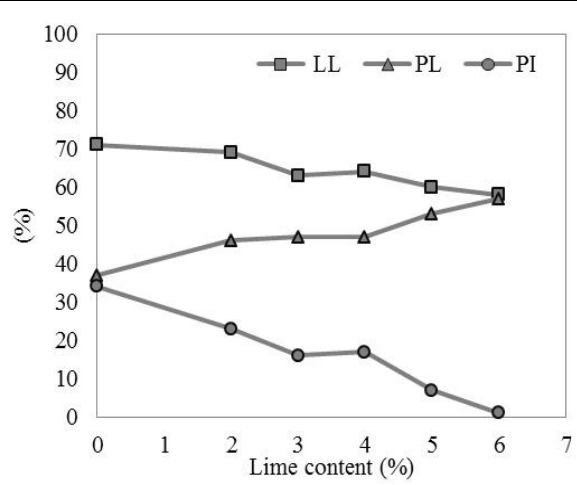

Fig. 1. Atterberg limits of mixtures with lime.

Optimum water content of the soil increase while the maximum dry unit weight (MDUW) of the soil decrease with
$5 \%$ of lime by weight. The soil samples for unconfined compression tests and CBR tests were prepared at the optimum water content and maximum dry density values found at modified Proctor tests above.

\section{A. Atterberg Limits and $p H$ Tests}

Liquid and plastic limit tests were conducted on the samples by mixing different amounts of lime to the clay soil. After adding lime, structural transformation and flocculation begins immediately and initial plastic properties of the soil changes in an hour.

The optimum lime amount to be used in the stabilization process was determined for preliminary design methods which are Eades and Grim [10] $\mathrm{pH}$ method and Atterberg limits methods [8].

Lime, in general, increases the $\mathrm{pH}$ of the environment and decomposes the silica and alumina over the clay surfaces leading to many reactions as defined above. In the research, dry soil was initially mixed with lime and then the Atterberg limit tests were conducted after 1 hour waiting time for initial reactions. The tests were conducted in accordance with ASTM 4318 [9]. Based on the Atterberg limit tests conducted, it was seen that as the amount of lime in the mixture was increased, substantial reductions in PI values were observed. Plasticity index values decreases to $7 \%$ with $5 \%$ hydrated lime as shown in the Fig. 1.

Eades and Grim [10] methods define the optimum lime content as the lime amount that brings the soil close to $\mathrm{pH}=12.4$ value. $\mathrm{pH}$ of the natural clay soil was found as 7.66 and $\mathrm{pH}$ increases with lime percent as shown in Fig. 2. The optimum $\mathrm{pH}$ value seems around $4-5 \%$ according to this methodology.

Optimum lime amount was chosen as $5 \%$ by weight for lime by using the $\mathrm{pH}$ and Atterberg limit test data together. Slag did not used for Atterberg limits and $\mathrm{pH}$ test since it does not create considerable changes in the plasticity properties of the soil.

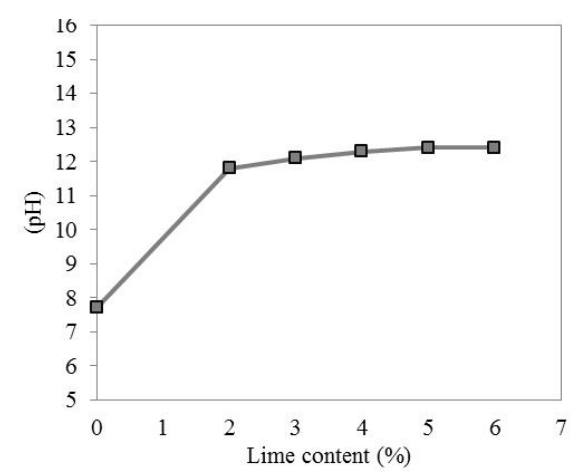

Fig. 2. $\mathrm{pH}$ values at various lime contents

\section{B. Unconfined Compression Tests}

Unconfined compression tests (UCS) have been conducted on Ankara clay at different slag-lime contents. These are natural clay (C), clay with $3.3 \%$ lime (L), clay with $3.33 \%$ lime and $3.33 \%$ slag (S), clay with $5 \%$ lime, clay with $5 \%$ lime and $3.33 \%$ slag.

The samples were prepared using the same methodology at the optimum water content and maximum dry density values found in the previously conducted modified Proctor compaction tests. The samples were cured for $0,1,7,28$ days and one year in the curing room. Curing conditions includes 
the following: (i) the ambient laboratory temperature varied between 17-25 C during curing period and (ii) the ambient humidity has been over $95 \%$. The unconfined compressive tests (UC) were performed to determine the effect of lime and slug additives on the strength of clay samples. Unconfined compressive tests were performed at two conditions of the clay with lime. In the first one of these conditions, dry pulverized clay was mixed with hydrated lime and water to bring to soil optimum water. The GGBFS slag was first pulverized and then sieved -150 micron sieve.

When the results of unconfined compression tests are examined, sharp strength increases are observed in the stabilized soil using the methodology [7]. According to the results of UCS test, the highest strength values were found particularly at $5 \%$ lime and $3.33 \%$ slag content. The unconfined compressive strength increased from $400 \mathrm{kPa}$ for natural clay to $2400 \mathrm{kPa}$ with lime and slag together as shown in Fig. 3. and Fig. 4. The increase in strength with slag-lime additives was higher than the strength achieved with additive lime alone. Based on these data, it could be said that slag and lime stabilization is more effective than lime stabilization alone.

\section{Scanning Electron Microscopy}

The samples were analyzed under scanning electron microscope (SEM). Both the natural and the lime stabilized clays were analyzed under electron microscope with 5000 times magnification as shown in Fig. 5 and Fig. 6.

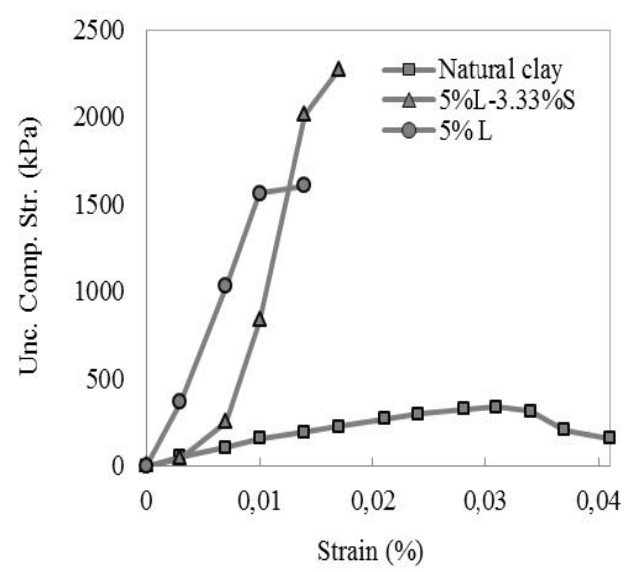

Fig. 3. UC tests.

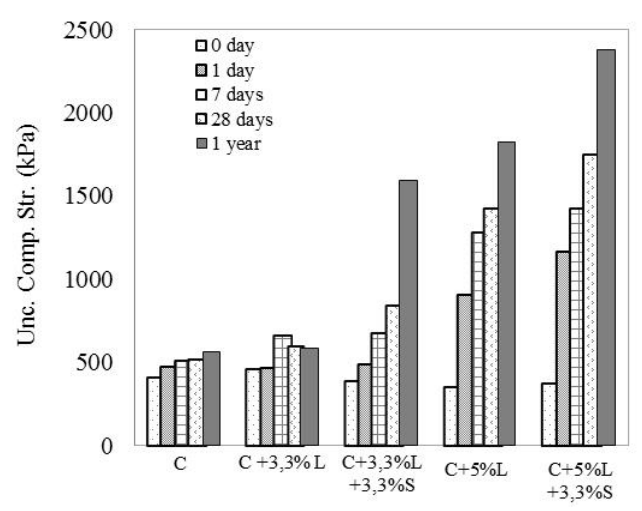

Fig. 4. UC strength test summary.

Based on these examinations, the silica and aluminum of the clay particles were easily detected and it has been observed that they have dissolved as a result of lime and water impact and have reacted with lime surrounding them.

The soil structure has transformed from a particle based form to a more integrated composition. The reactions led to form alumina and silica hydrate gels, which are cementation products of lime stabilization. This process is called pozzolonic reaction. The reason for strength increases of lime stabilized soils in the long term is mainly due to the pozzolonic reactions.

\section{California Bearing Ratio (CBR) Tests}

For CBR tests, the materials were mixed at their optimum water content and prepared at predetermined additive contents. The samples were compacted after one hour of mixing. The prepared samples were cured 28 days before the soaked CBR experiments. The tests were performed in accordance with ASTM D 1883-87 [9]. The results obtained from CBR tests are presented in Fig. 7.

The results show that, there were sharp increases in the soaked CBR values. The value was increased from 4 for natural brown colored Ankara clay to 184 with 5\% lime and $3.3 \%$ pulverized slag. The swelling during soaking was found as less than $1 \%$ for stabilized samples. The sharp increases in CBR values would decrease the pavement layer thickness and decrease the cost of construction.

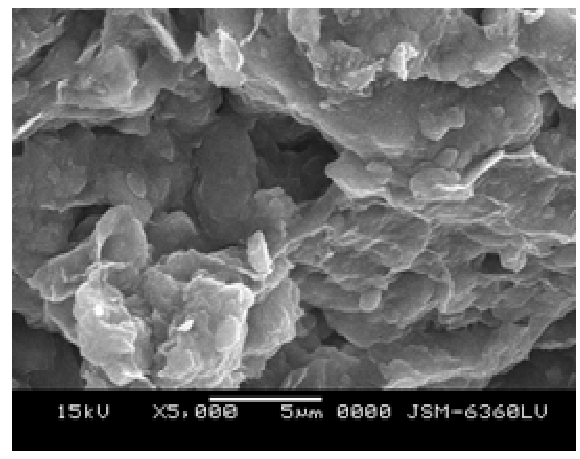

Fig. 5. Natural clay SEM 5000X magn.

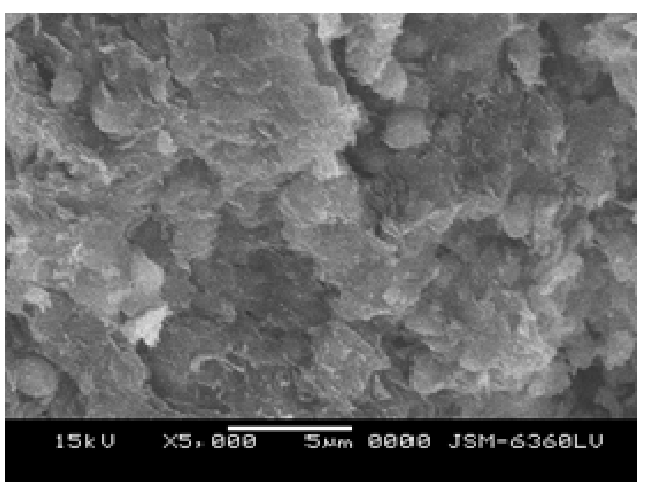

Fig. 6. Clay with 5\% hydrated lime SEM 5000X magn.

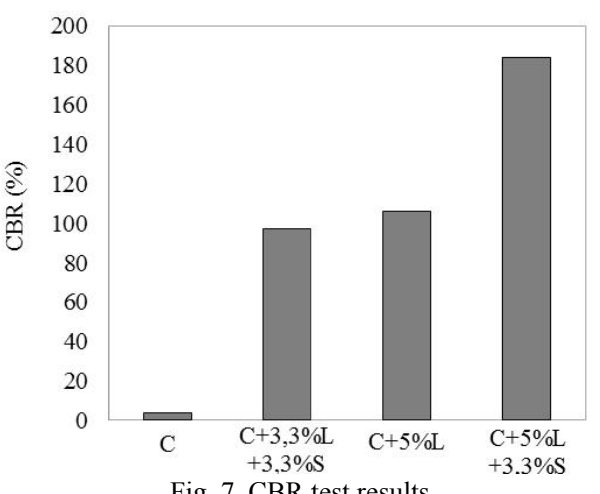

Fig. 7. CBR test results 
As a result, stabilization could produce high and long-lasting strength gains. This would also dramatically reduce environmental impact throughout construction and ongoing use of access road pavement.

\section{CONCLUSIONS}

Grain size of the slag is very important for stabilization; grain size of the slag directly affects the reactions in the soil. Although it is impossible to use the slag without any operation like pulverizing or sieving as an additive for soil, it can be used directly as a granular road material in places close to the factory. Although slag-lime and clay mixtures do not affect optimum water contents of clay significantly, slag-lime decreases in dry density and has a smooth proctor curve. Then, the soil transforms into a rapid structure and the modulus of elasticity increases. The strength increases with pulverized slag and lime was found greater than the lime alone. Since lime is widely used as an additive for road construction works. The usage of lime and slag together probably will have a chance for road construction works. This method should also be studied with more clay samples and also in a field application before routine usage.

Lime-slag contents for the improvement of a clay type of soil can be chosen as follows; first the optimum lime can be found using Atterberg limits and $\mathrm{pH}$ method without slag and then slag content can be determined by using lime to slag ratio 1 to 1.5 .

Using performance tests such as CBR and UCS tests can be conducted at 3 different percentages as a check around the predetermined contents according to the objective of the study.

By using lime-slag stabilization for road materials the following benefits are achieved more than lime-stabilization; (i) the volume of the fill material and the deformations in the fill layers will decrease because of very high CBR and unconfined compressive strength values (ii) the slag will prevent the ettringite formation that occurs in lime-stabilization with sulfate rich soils and therefore decrease swelling effect of lime-stabilized soils (iii)

The slag $-150 \mu \mathrm{m}$ can be produced in the factory by pulverizing as an additive and can be used for road constructions. Therefore slag can be used as an additive even at great distances from the factory. And finally the slag will turn from a by-product into a valuable product for road construction.

\section{REFERENCES}

[1] J. B. Croft, "The process Involved in the lime stabilization of clay soils," Australian Research Board, vol. 2, pp. 1169-1203, 1964.

[2] J. Locat, M. Berube, and M. Choquette, "Laboratory investigations on the lime stabilization of sensitive clays shear strength development," Canadian Geotechnical Journal, vol. 27, pp 294-303, 1990.

[3] W. Tasong, S. Wild, and R. J. D. Tilley, "Mechanisms by which ground granulated blast furnace slag prevents sulphate attack of lime-stabilized kaolinite," Cement and Concrete Research, vol. 29, pp 975-982, 1999.

[4] M. Cevik, "The production of light-weight aggregates using ground granulated blast furnace slag," in Proc. the Symposium of Usage of Industrial Wastes in Civil Engineering Applications, Turkey, 1993, pp. $235-242$

[5] S. Wild, J. M. Kinuthia, G. I. Jones, and D. D. Higgins, "Suppression of swelling associated with ettringite formation in lime stabilized sulphate bearing clay soils by partial substitution of lime with G.G.B.S," Engineering Geology, 1999, vol. 51, pp. 257-277.

[6] V. G. Green, "Ground and great: Soil stabilization with slag," Building Research \& Information, vol. 28, no. 1, England, pp. 70-72, 2000.

[7] G. Bilgen, "Soil stabilization using ground granulated blast furnace slag," MS Thesis, Kocaeli University.2004.

[8] A. Kavak and A. Akyarlı, "A field application for lime stabilization," Environmental Geology, vol. 51, no. 6, pp. 987-997, 2007.

[9] J. E. Bowles, Engineering Properties of Soils and Their Measurements, 4th edt.1992, McGraw-Hill, NY.

[10] J. E. Eades and R. E. Grim, "A quick test to determine lime requirements for lime stabilization," Highway Research Board, 1963, no. 139 , pp. $61-72$.

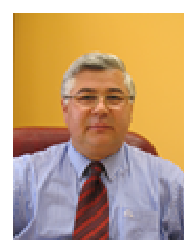

A. Kavak was born in Turkey in 1962. He graduated from Middle East Technical University, Civil Engineering Department in Ankara/Turkey and he completed $\mathrm{PhD}$ in Bogazici Universit, Institute Of Science and Technology Civil Engineering Department, Istanbul, Turkey.

Aydin has been an associate professor in Kocaeli University, Turkey since 2012. He has performed on to enhance laboratory test and research on the soil stabilization with lime, polymers, silicon, cement and waste materials Some titles of Kavak's papers are: A. Kavak and A. Akyarl1, "A field application for lime stabilization," Environmental Geology, vol. 51, no. 6, 2007; U. Mutman and A. Kavak, "An in situ low-pressure grouting application," in Proc. the Institution of Civil Engineers-Geotechnical Engineering, 165 GE1, pp. 1-14, 2012; A. Kavak and F. Tüylüce, "Treatment of marine clay with hydrated lime and quicklime," Journal of ASTM International, STP 1557, pp. 90-105, 2011.

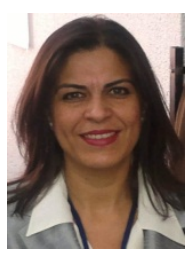

G. Bilgen was born in Turkey in 1972. She graduated from Anadolu University Civil Engineering Department in Eskisehir/Turkey and completed her PhD in Kocaeli University, Institute of Science and Technology - Civil Engineering Department, Kocaeli, Turkey.

Gamze worked in Karaelmas University among 1999-2011 and she has been Assist Professor in Bulent Ecevit University, Turkey since 2011. She has performed on to enhance laboratory test and research on the soil stabilization with waste material. Some titles of Bilgen's papers are: A. Kavak and G. Bilgen, "Effects of seawater on geotechnical properties of a clay soil," Fresenius Environmental Bulletin, vol. 19, no 8a, pp. 1623-1628, 2010; A. Kavak, G. Bilgen, and U. Mutman, "In-situ modification of a road material using a special polymer," Scientific Research and Essays, vol. 5, no. 17, pp. 2547-2555, 2010; A. Kavak, G. Bilgen, and O. F. Capar, "Using ground granulated blast furnace slag with seawater as soil additives in lime-clay stabilization," ASTM, vol. 8, no. 7, pp. 12, 2011. 